Черкаського університету: Серія педагогічні науки. - № 165. - С. 144-148. 2. Балл Г. А. Теория учебных задач : Психолого-педагогический аспект / Г. А. Балл. М. : Педагогика, 1990. - 184 с. З. Левина М. М. Технология профессионального педагогического образования : [учеб. пособ.] / М. М. Левина. - М. : Академия, 2001. 270 с. 4. Матюшкин А. М. Проблемные ситуации в мышлении и обучении : [пособ.] / А. М. Матюшкин. - М. : Педагогика, 1972. - 209 с. 5. Махмутов М. И. Проблемное обучение. Основные вопросы теории : [учеб. пособ.] / М. И. Махмутов. - М. : Педагогика, 1975. - 368 с. 6. Низамов Р. А. Дидактические основы активизации учебной деятельности студентов : [пособ.] / Р. А. Низамов. - Казань : Изд-во КГУ, 1995. - 302 с. 7. Омеляненко В. Л. Педагогіка : завдання і ситуації : Практикум: [навч.-метод. посіб.] / В. Л. Омеляненко, А. І. Кузьмінський, Л. П. Вовк. - К. : ЗнанняПрес, 2006. - 423 с. 8. Савченко О. Я. Дидактика початкової освіти : [підручн.] / О. Я. Савченко. - К. : Грамота, 2012. - 504 с. 9. Сухомлинський В. О. Серце віддаю дітям / В. О. Сухомлинський // Вибрані твори : в 5 т. - Т. 3. - К. : Рад. шк., 1977. C. 53-54. 10. Топузов О. М. Проблемне навчання : теорія і практика : [монографія] / О. М. Топузов. - К. : Фенікс, 2007. - 304 с.

УДК 372.881.111.1:37.02

Ірина Сімкова

\title{
СУЧАСНИЙ СТАН НАВЧАННЯ МАЙБУТНІХ БАКАЛАВРІВ-ФІЛОЛОГІВ УСНОГО ДВОСТОРОННЬОГО ПЕРЕКЛАДУ В НАУКОВО-ТЕХНІЧНІЙ СФЕРІ
}

Сімкова I. О. Сучасний стан навчання майбутніх бакалаврів-філологів усного двостороннього перекладу в науково-технічній сфері.

У статті на основі аналізу, порівняння й узагальнення освітньо-кваліфікаційних характеристик, освітньо-професійних програм, довідника кваліфікаційних характеристик професій працівників та різних зарубіжних стандартів у галузі усного перекладу розглядається сучасний стан навчання майбутніх перекладачів усного перекладу в науково-технічній сфері.

Ключові слова: майбутні філологи, навчання усного перекладу, освітньокваліфікаційна характеристика, освітньо-професійна програма, професійний стандарт.

Симкова И. О. Современное состояние обучения будущих бакалавров-филологов устному двустороннему переводу в научно-технической сфере.

В статье на основе анализа, сопоставления и обобщения образовательноквалификационных характеристик, образовательно-профессиональных программ, справочника квалификационных характеристик профессий служащих и различных зарубежных стандартов в области устного перевода рассматривается современное состояние обучения будущих переводчиков устному переводу в научно-технической сфере.

Ключевые слова: будущие филологи, обучение устному переводу, образовательно-квалификационная характеристика, образовательнопрофессиональная программа, профессиональный стандарт.

Simkova I. O. The current state of future bachelor-philologists training in bilingual interpreting in scientific and technical sphere.

On the ground of analysis, contrast, and unification of educational-qualification 
characteristics, educational-professional programs, job description catalogue, and different foreign standards in interpreting the current state of future interpreters training in interpreting in scientific and technical sphere is considered in the article.

Key words: educational-qualification characteristics, educational-professional programs, future philologists, interpreting training, professional standards.

Якість підготовки бакалавра в сучасних умовах визначається не лише рівнем його знань, але й загальноінтелектуальним, професійно-творчим потенціалом, що дає можливість майбутньому перекладачу впевнено вирішувати складні професійні завдання. На жаль, нині наявні суперечності щодо вимог, які постають перед майбутніми бакалаврами-філологами та рівнем їх практичної підготовки до перекладацької діяльності та щодо необхідності підвищення рівня сформованості готовності майбутніх бакалаврів-філологів до професійної діяльності та недоліків у навчально-методичному забезпеченні цього процесу. За таких умов звернення до проблеми дослідження сучасного стану навчання майбутніх перекладачів усного двостороннього перекладу є не лише актуальним, але й необхідним.

Mema cmammi- дослідити сучасний стан навчання майбутніх бакалаврівфілологів усного двостороннього перекладу в науково-технічній сфері шляхом аналізу професійних стандартів у галузі перекладу та змісту програм його навчання.

Освітні вимоги до навчання перекладу на рівні бакалавра представлені в освітньо-кваліфікаційних характеристиках (ОКХ) і освітньо-професійних програмах (ОПП). Більш загальні вимоги до підготовки майбутніх перекладачів ми знаходимо в таких документах, як Довідник кваліфікаційних характеристик професій працівників, Стандарт Міжнародної асоціації усних перекладачів (АIIC), Свропейський кваліфікаційний стандарт EN-15038, Національний професійний стандарт усних перекладачів (Великобританія), Стандарт контролю якості послуг усного перекладу (США) і Національний стандарт контролю якості усного перекладу у громадськополітичній сфері (створено Професійною асоціацією мовознавців (AILIA) за підтримки різних асоціацій усних перекладачів Across Languages Translation and Interpretation Service, a London, Ontario based community interpreter service and the American National Council on Interpreting in Healthcare).

Проаналізуємо освітні державні стандарти зі спеціальності «Переклад» і освітньо-професійні програми, розглянемо професійні стандарти в галузі перекладу в Україні та за їі межами, паралельно роз'яснюючи окремі терміни.

Під державним стандартом зі спеціальності «Переклад» ми розуміємо сукупність норм, що визначають зміст вищої професійної освіти, обсяг навчального навантаження, засоби діагностики якості освіти та рівня підготовки бакалаврівфілологів, а також нормативний термін навчання. Такий стандарт повинен визначати обов'язковий мінімальний зміст навчальних програм, обсяг навчального навантаження майбутніх філологів, вимоги до рівня їх підготовки у ВНЗ і бути основою нормативних документів (навчальних планів, навчальних програм тощо). Нині в Україні функції такого стандарту виконують освітньо-кваліфікаційна характеристика й освітньо-професійна програма.

OKX бакалаврів за напрямом підготовки Філологія $є$ державним нормативним документом, у якому узагальнюється зміст навчання, тобто відображаються цілі освітньої та професійної підготовки, вимоги до рівня їх компетентностей, інші важливі властивості та якості майбутніх перекладачів.

Серед розділів, які містять ОКХ напряму підготовки 6.020303 Філологія 3 
кваліфікацією «Бакалавр 3 філології, перекладач 3 іноземної мови» освітньокваліфікаційного рівня «Бакалавр», ми знаходимо перелік виробничих функцій, типових задач та компетентностей щодо розв'язання типових задач професійної діяльності, перелік умінь, що забезпечують наявність цих компетентностей. Аналіз ОКХ, розроблених різними університетами (НТУУ «КПІ», НДУ ім. Т. Г. Шевченко, ДонДУУ, МАУП тощо), показує, що їх зміст навчання загалом схожий, однак існують різні класифікації компетентностей і виробничих функцій, що зумовлює вимоги до знань, навичок і вмінь.

Проаналізувавши ОКХ різних університетів, ми виокремили виробничі функції, що є однаковими: організаційна (наприклад, упровадження організаційних заходів для підвищення якості перекладацької діяльності), управлінська (наприклад, керівництво роботою команди перекладачів (бюро перекладів), контрольна (наприклад, здійснення контролю в межах своєї професійної діяльності), прогностична (наприклад, прогнозування дій безпосередньо спрямованих на виконання завдань), технологічна (наприклад, засвоєння накопичених освітнім та фаховим простором знань про інноваційні технології навчання i перекладу), технічна (наприклад, виконання професійної діяльності методом застосування новітніх форм і засобів діловодства), в деяких ОКХ виокремлюється також дослідницька виробнича функція (наприклад, складання тематичних оглядів за зарубіжними матеріалами тощо). Загалом визначається від 5 до 7 виробничих функцій, для них використовуються різні назви (проектувальна, текстотвірна тощо), однак за змістом вони збігаються із розглянутими вище.

Згідно з українськими освітніми стандартами об'єктами професійної діяльності фахівця в галузі перекладу є дисципліни, зміст яких спрямований на формування таких компетентностей: соціально-особистісних (розуміння та сприйняття етичних норм поведінки відносно інших людей тощо), загальнонаукових (базові уявлення про основи філософії, психології, педагогіки, мовознавства тощо), інструментальних (здатність до письмової й усної комунікації рідною та іноземними мовами тощо), загальнопрофесійних (комунікативна, яка передбачає мовну, мовленнєву i соціокультурну) і спеціалізовано-професійних (професійно-академічна, професійнотехнічна, текстотвірна).

ОПП бакалаврів за напрямом підготовки Філологія - державний нормативний документ, у якому узагальнено зміст навчання, встановлено вимоги до змісту, обсягу й рівня освітньої та професійної підготовки майбутніх перекладачів.

Аналіз ОПП, розроблених різними університетами (НТУУ «КПІ», НДУ ім. Т. Шевченка, ДонДУУ, МАУП тощо), показав, що вимоги до змісту навчання майбутніх перекладачів подібні. Усі вони мають нормативні та варіативні частини, до нормативної частини входять: цикл гуманітарної та соціально-економічної підготовки, цикл математичної та природничо-наукової підготовки, цикл професійної та практичної підготовки. Варіативна частина містить: дисципліни самостійного вибору ВНЗ і дисципліни вільного вибору студентів (гуманітарний складник і професійний складник). В ОПП міститься інформація про концепцію підготовки, галузь використання, розподіл змісту освітньо-професійної програми тощо.

На відміну від вищезгаданих документів, професійні стандарти в галузі перекладу не $\epsilon$ нормативними документами. Скоріше їх можна визначити як принципи, які покладено в основу взаємодії «замовник - виконавець»: виконавець повинен знати, які вимоги він має право висувати замовникові, замовник також повинен знати, що саме він може вимагати від виконавця. Ці стандарти встановлюють особливості перекладацької 
професії, зокрема фізичне та розумове навантаження перекладачів, умови їхньої роботи. Дотримання їх у професійній діяльності необхідне для забезпечення оптимальної якості перекладацьких послуг [3].

Наприклад, довідник кваліфікаційних характеристик професій працівників містить кваліфікаційні вимоги до перекладачів, їх завдання і обов'язки, а також обсяг знань. Відповідно до нього розрізняють перекладачів з різними кваліфікаційними вимогами: провідний перекладач 3 повною вищою освітою і стажем роботи не менше 2 років; перекладач I та II категорії з повною вищою освітою і різницею вимог щодо магістра і спеціаліста; перекладач 3 повною вищою освітою без вимог до стажу роботи [1].

Професійні стандарти Міжнародної асоціації усних перекладачів (Тhe International Association of Conference Interpreters) також не визначають компонентний склад та рівень компетентностей майбутніх перекладачів. Вони регулюють показники якості самого перекладу, робочий день перекладача, тарифікацію, кількість перекладачів для кожного з видів усного перекладу (синхронний, нашіптування, послідовний) тощо.

Схожу інформацію щодо якості перекладу містить i Європейський кваліфікаційний стандарт EN-15038, який був затверджений і офіційно оприлюднений Європейським комітетом із стандартизації (СКС) у 2006 році. Національні органи із стандартизації країн членів ЄКС, a їх більше 35 , прийняли до виконання вищезгаданий стандарт, однак з певною модифікацією [2].

Національний стандарт контролю якості усного перекладу в громадськополітичній сфері (NSGCIS) містить вимоги щодо кваліфікації перекладача (володіння перекладацькою, лінгвістичною, пошуковою, технічною та міжособистісною компетентностями), ролі й обов'язків перекладачів, обов'язки бюро перекладів, у додатках містяться вимоги до виконання юридичного перекладу та перекладу у сфері охорони здоров'я, стандарти практичної діяльності та вісім етичних принципів, яких слід дотримуватися перекладачам [5].

Коротко розглянемо кожний 3 них: 1) принцип точності й правильності, його мета: збереження змісту повідомлення; 2) принцип конфіденційності, його мета: захист конфіденційної інформації; 3) принцип неупередженості, його мета: уникнення упередженого ставлення з боку перекладача до будь-якої сторони, що бере участь у комунікації; 4) принцип поваги, його мета: демонстрація визнання гідності всіх сторін комунікації; 5) принцип дотримання рольових меж, його мета: захист професійної гідності, забезпечення стабільного емоційного стану і фізичної безпеки перекладача; 6) принцип відповідальності, його мета: визнання відповідальності за якість роботи перекладача; 7) принцип професіоналізму, його мета: визнання відповідальності за свої дії, вчинки і поведінку загалом; 8) принцип постійного підвищення рівня знань, його мета: досягнення найвищого рівня компетентності [5]. Усі ці принципи повинні бути враховані під час розроблення методики для формування фахової компетентності перекладача.

В американському стандарті контролю якості послуг усного перекладу (F 2575 06) розглянуто чинники, які визначають якість перекладацьких послуг, та встановлено критерії для кожного компонента. Ці критерії визначають мінімальні стандарти якості послуг у перекладацькій діяльності відповідно до чітко встановлених вимог. Поданий у них аналіз потреб визначає процедуру, відповідно до якої обирається вид перекладу [6].

У Британському національному професійному стандарті усних перекладачів 
(National Occupational Standards in Interpreting) визначено зміст поняття «усний переклад» та роль у ньому перекладача, принципи професійної діяльності, для кожного виду усного перекладу надано характеристики для здійснення професійної діяльності і перелік знань та умінь, необхідних для виконання різних видів перекладу [4].

Отже, стратегія побудови навчання перекладу, розроблення навчальних матеріалів й укладання держаного стандарту повинна враховувати як основні національні документи, так і допоміжні міжнародні. До основних ми відносимо: норми Закону України «Про вищу освіту», ОКХ підготовки бакалавра, вимоги ОПП до підготовки бакалавра, професійні стандарти в галузі перекладу.

Допоміжними матеріалами можуть бути: Європейський кваліфікаційний стандарт EN-15038, Національний професійний стандарт у галузі усного перекладу (National Occupational Standards in Interpreting), Міжнародна стандартна класифікація освіти (ISCED - 97), Структури кваліфікацій для Європейського простору вищої освіти (The framework of qualifications for the European Higher Education Area) тощо. На нашу думку, прийняття до уваги зазначених документів забезпечить єдиний підхід до визначення завдань і обов'язків майбутніх перекладачів, їх кваліфікаційних вимог i складання програм їхньої підготовки.

\section{Література}

1. Довідник кваліфікаційних характеристик професій [Електронний ресурс].Режим доступу : http://www.dnaop.com/html/1430_37.html 2. Сімкова I. О. Вимоги до фахової компетенції майбутніх перекладачів : європейський стандарт / Ірина Олегівна Сімкова / Международное сотрудничество в образовании в условиях глобализации. 2013. - Ч. 1.- С. 273-276. 3. Стандарти професії: письмовий та усний переклад [Електронний ресурс]. - Режим доступу : http://ua.convdocs.org/docs/index-44390.html 4. National Occupational Standards in Interpreting. - London : CILT, National Centre for Languages, 2006. - 40 p. 5. National Standard Guide for Community Interpreting Services. - Toronto : AILIA, 2007. - 45 p. 6. US Standard Guide for Quality Assurance in Translation F 2575-06.

УДК 378.147-057.87:81'25:004

Ростислав Тарасенко

\section{ПІДГОТОВКА МАЙБУТНІХ ПЕРЕКЛАДАЧІВ ДО ПРОФЕСІЙНОЇ ДІЯЛЬНОСТІ В СУЧАСНОМУ ІНФОРМАЦЙННОМУ ПРОСТОРІ}

Тарасенко Р. О. Підготовка майбутніх перекладачів до професійної діяльності в сучасному інформаційному просторі.

Розглянуто питання діяльності майбутніх перекладачів в умовах сучасного інформаційного простору. Висвітлено формувальний уплив його елементів на інформаційні компетенції у процесі підготовки перекладачів відповідно до сучасних вимог інформаційного суспільства.

Ключові слова: інформаційне суспільство, інформаційний простір, інтернетресурси, корпуси (бази даних), інформаційні технології, перекладач.

Тарасенко Р. А. Подготовка будущих переводчиков к профессиональной деятельности в современном информационном пространстве.

Рассмотрены вопросы деятельности будущих переводчиков в условиях современного информационного пространства. Освещено формирующее влияние его 